Print ISSN: 2234-3040 / Online ISSN 2234-3059

doi:10.13106/eajbm.2018.vol8.no3.13

\title{
The Influence of Bullying on Burnout through Workaholism and Perceived Organizational Support*
}

\author{
Youngkeun Choi**
}

Received: April 8, 2018. Revised: April 23, 2018. Accepted: July 15, 2018.

\section{Abstract}

Purpose - This study examined workplace bullying as a situational antecedent of workaholism and burnout as a consequence of workaholism and explored the mediating role of workaholism and the moderation effect of perceived organizational support.

Research design, data, and methodology - This study collected data from 319 employees in South Korean companies through a survey method.

Results - First, job-related bullying promotes a compulsive and excessive drive to work. However, person-related bullying was positively related to the tendency to work excessively hard. Second, only working excessively shows positive relationship with only exhaustion excepting cynicism. Third, although bullied employees may reserve their personal resources through workaholism in short time, it drives them to be workaholic, which leads them exhausted in turn. Finally, perceived organizational support decreases the effect of job-related bulling on both of working compulsively and working excessively.

Conclusions - First, this study suggests workplace bullying as a situational antecedent and verify burnout as a consequence of workaholism. Second, it investigate the mediating role of workaholism and the moderation effect of perceived organizational support. Practically, When they find workaholic employees, they should investigate if workplace bullying exists through face-to-face talk. If necessary, they should decide personal transfer to the other department or work team.

Keywords: Workaholism, Burnou, Workplace Bullying, Perceived Organizational Support.

JEL Classifications: C12, C83, M12, M14.

\section{Introduction}

Oates (1971) coined the term "workaholism" to describe an addiction to work compulsion or uncontrollable and ever-increasing need to work. As an influential definition, Spence and Robbins (1992) suggested that a real work addict is highly work involved, feels compelled or driven to work because of inner pressures, and is low in enjoyment of work. Scott, Moore, and Miceli (1997) suggested the following three critical characteristics of workaholics. First, they tend to spend a large amount of time on work activities. Second, they frequently think about work when not

* This study was supported by Sangmyung University 2017 Research Fund.

** Associate Professor, Division of business administration, Sangmyung University, Korea.

Tel: +82-2-781-7540, E-mail: penking1@smu.ac.kr at work, suggesting they are obsessed with work. Finally, they tend to work beyond organizational and monetary expectations, needs, or demands. $\mathrm{Ng}$, Sorensen, and Feldman (2007) defined workaholism as reflecting affect, cognition, and behavior.

As workaholics compulsively invest much effort into their work (Scott et al., 1997), workaholism is defined as a progressive and fatal disease in which a person is addicted to the process of working (Burke, 1999; Taris et al., 2008). Therefore, finding ways to effectively reduce or prevent workaholism is important and relies on a better understanding of its antecedents. However, the reasons for people to work hard may differ, and do not inevitably indicate workaholism (Porter, 1996). Previous studies have shown that demographic characteristics (Spence \& Robbins, 1992), a stressful job demands ( $\mathrm{Ng}$, Sorensen, \& Feldman, 2007) and an organizational culture that values high work pressure (Buelens \& Poelmans, 2004) relate to workaholism. 
The important research subject of existing study is how specific cognitive factors exert influence on workaholism (McMillan, O'Driscoll, \& Burke, 2003). A related advantage of a cognitive approach is that it adopts an optimistic point of view with regard to changing the workaholic behavior; that is, if maladaptive thought patterns lead to workaholic behavior, workaholism may be decreased through adjustment of dysfunctional cognitions (McMillan \& O'Driscoll, 2008). Furthermore, there are some reasons to believe that workaholism mediates the relationship between cognitive antecedents and burnout. For instance, Taris, Van Beek, and Schaufeli (2010) showed that the association between perfectionism and burnout (emotional exhaustion) was mediated by workaholism. However, few researches are interested in situational antecedents of workaholism. The present study aims to show that situational antecedents have an indirect impact on burnout through workaholism. Building upon the conservation of resources theory (Hobfoll, 1989, 2002), this study examines reciprocal relationships between situational antecedents, workaholism, and burnout. The focus is on workplace bullying as a specific situational antecedent.

\section{Theoretical Background and Hypothesis}

Workplace bullying was defined as situations in which one or more individuals persistently over a period of time perceive themselves to be on the receiving end of negative actions from one or several persons, in a situation where the target (employee) of bullying has difficulty defending him or herself against these actions (Einarsen, 2005). The latter definition reveals the most important elements of workplace bullying - that is, negativity, persistency, duration, and power imbalance (inferior position of a targeted person). Since the introduction of workplace bullying phenomenon, extensive research has been conducted related to the negative consequences (Astrauskaite et al., 2010; Hogh et al., 2011). The early research demonstrated that exposure to bullying may have highly detrimental effects on targets' psychological health. Yet, the studies also show that some targets exhibit only moderate levels of stress as, for instance, depression or post-traumatic stress disorder (PTSD).

The conservation of resources (COR) theory explains that people expend resources during stressful situations and that they strive to maintain and protect their remaining resources and suggests that stress occurs when there is a threat to valued resources, an actual loss of resources, or insufficient gain following the investment of resources (Hobfoll, 1989). From a COR perspective, stress occurs when there is a threat to valued resources, an actual loss of resources, or insufficient gain following the investment of resources. For example, workplace bullying produces negative effects by threatening a person's pool of personal resources, where resources are defined as those objects, personal characteristics, conditions, or energies that are valued in their own right or that are valued because they act as conduits to the achievement or protection of valued resources (Hobfoll, 2001). The experience of workplace bullying depletes personal resources such as one's sense of self-worth, time, and physical energy. Bullied employees also experience diminished physical and mental health resources (Nielsen \& Einarsen, 2012).

The socio-cultural perspective on addiction suggests that addiction is generally a product of maladaptive cognition from the social and cultural experiences that individuals have in their childhood, adolescence, and adulthood (Hirschman, 1992; Thombs, 1994). Furthermore, some addictions (e.g., drinking or drug usage) can fulfill social functions of releasing the addict from normal social obligations (e.g., attendance at family events). Socio-cultural experiences often arise in the workplace. The employees who are being bullied in workplaces can be highly involved in their jobs to overcome the loss of their personal resources from workplace bullying. Based on these indications, this study expects that workplace bullying might be a precursor of workaholism. This paper tests the assumption that when employees who are being bullied in workplaces, they are vulnerable for developing workaholism. For that reason, I formulated the following hypothesis. $<$ Hypothesis $1>$ Workplace bullying will be positively
related to workaholism.

There are strong indications that workaholism has serious implications for employee health, particularly in terms of the level of burnout (Andreassen et al., 2007; Burke, 1999; Taris et al., 2008). Because workaholics work hard, they seem to deplete their resources to the point of near exhaustion (Maslach, 1986). This is consistent with studies that show that working long hours is related to increased levels of strain (Van der Hulst, 2003). A lack of recovery might explain why workaholism translates into burnout-that is, hardworking employees may not have enough time left to recover from their work efforts by relaxing or sleeping (Sonnentag \& Zijlstra, 2006; Van Wijhe et al., 2013; Kim et al., 2016), which could result in fatigue and, eventually, exhaustion. Nonetheless, the causal direction of the relationship between workaholism and exhaustion has not been established in earlier research. Longitudinal research can shed more light on the direction of the relationship between workaholism and burnout. This study anticipates that, over time, a compulsive drive to work and devoting a great deal of time to work will have negative consequences in terms of increased burnout. For that reason, I formulated the following hypothesis.

$<$ Hypothesis 2> Workaholism will be positively related to burnout. 
The present study aims to focus on the mechanism linking situational antecedents to burnout, through workaholism. The causal nature of this relationship remains untested. Furthermore, there is reason to believe that workaholism mediates the relationship between situational antecedents and burnout. For instance, Taris et al. (2010) showed that the association between perfectionism and burnout (emotional exhaustion) was mediated by workaholism.

As outlined previously, several studies have linked exposure to workplace bullying to burnout (Bowling \& Beehr, 2006; Nielsen \& Einarsen, 2012; Meliá \& Becerril, 2007; Sá \& Flemming, 2008; Laschinger et al., 2010). Especially, in their theoretical model synthesizing empirical studies of the effects of workplace bullying, Nielsen and Einarsen (2012) argue that bullying influences negative job-related health outcomes (such as burnout and job turnover) by activating mechanisms which may over time deplete available coping resources. And, burnout results from prolonged exposure to negative demands in the workplace (Leiter \& Maslach, 2004). Workplace bullying is characterized as targeted negative acts that persist over time which are stressful for targets of bullying and may potentially deplete psychological resources needed to cope with these bullying behaviors (Einarsen, Matthiesen, \& Skogstad, 1998).

When employees experience the loss of their personal resources from workplace bullying, they tend to be highly involved in their jobs to overcome the loss of their personal resources in workplaces. However, although they may reserve their personal resources through workaholism, it drive them to be workaholic, which leads them into burnout paradoxically. Accordingly, the following hypothesis is established.

\section{$<$ Hypothesis 3> Workaholism will mediate the relationship between workplace bullying and burnout.}

The conservation of resources theory predicts that people will reduce their net loss of resources by investing in or drawing from other resources that they possess or are accessible from their environment. In an elaboration of the conservation of resources theory, ten Brummelhuis and Bakker (2012) proposed that in addition to their own resource pool, the environments in which people are embedded may also serve as a resource that can be used to buffer the spillover effects of aversive home experiences into the workplace. One workplace resource that has been shown to buffer the stressor-strain relationship is perceived organizational support. Organizational support theory suggests that employees form expectancies of support based on the degree to which the organization both values employees' contributions and demonstrates concern for their well-being (Eisenberger et al., 1986; Moon et al., 2016; Yang et al., 2015).

Based on organizational support theory, this study expects perceived organizational support to buffer the relationship between workplace bullying and workaholism for several reasons. First, perceived organizational support provides access to relevant resources at work, which can help bullied employees replenish or conserve their stock of resources. For instance, instrumental support in the form of organizational policies like personal leave and flexible work arrangements can offer respite from work and opportunities for bullied employees to cope with bullying people. Thus, a supportive work environment could also help in reducing their unnecessary energy, which may help conserve remaining resources (Ray \& Miller, 1994). Second, a supportive work environment signals that the employee is a valued member of the organization, which can lead to resource accumulation through its positive impact on one's sense of self-worth and its satisfaction of the fundamental human need for belongingness (Rhoades \& Eisenberger, 2002). Self-esteem and feeling a sense of belonging are both important socio-emotional resources and so events or experiences that replenish or increase them can potentially counteract the resource demands that coping with workplace bullying places on the employee. Therefore, when employees who are being bullied in workplaces perceive organizational support, they can access to physical resources at work which can help bullied employees replenish or supplement mental resources through its positive impact on one's sense of self-worth and its satisfaction of the fundamental human need for belongingness. In turn, they don't need to be highly involved in their jobs to overcome the loss of their personal resources from workplace bullying. Thus, this study offers the following predictions:

<Hypothesis 4> The relationship between workplace bullying and employees' workaholism is decreased by their perceived organizational support.

\section{Methodology}

\subsection{Sample}

The objective of the study was to identify the factors of organizational behaviors related to workaholism based on empirical analysis. These factors can be identified by measuring the organization's members' perceptions of their workplace situation. The survey research method is very useful in collecting data from a large number of individuals in a relatively short period of time and at a lower cost. Hence, for the current study, the questionnaire survey was used for data collection.

This study is based on responses from white-colored workers in Korean companies. Only 319 responses were useable for analysis. Among the participants, 152 (47.6\%) were men and 167 (52.4\%) women. The age distribution includes $24.1 \%$ in their 20 s, $25.7 \%$ in their 30 s, $25.4 \%$ in 
their 40s, and $24.8 \%$ in their $50 \mathrm{~s}$. The distribution of company size based on number of employees is $21.9 \%$ with less than $10,28.8 \%$ with $11-50$ employees, $29.5 \%$ with 51-300 employees, $7.8 \%$ with 301-1,000 employees, and $11.9 \%$ with more than 1001 employees. With regards to the industry that their company is involved in, $27.9 \%$ are in manufacturing, $10.3 \%$ in construction, $33.2 \%$ in service, $6.0 \%$ in public agency, $8.2 \%$ in wholesale-retail, and $14.4 \%$ are in other industries. Most of the respondents hold a staff position (42.3\%), 18.5\% are assistant managers, $15.4 \%$ are managers, $14.4 \%$ are senior managers, $6.9 \%$ are directors, while $2.5 \%$ hold other position levels. According to tenure, $51.1 \%$ have been in their company for less than 5 years, $25.5 \%$ for $5-10$ years, $13.8 \%$ for $10-15$ years $=, 4.4 \%$ for 15 -20 years, and $6.3 \%$ for more than 20 years. Based on level of highest educational attainment, $0.6 \%$ only finished middle school, $16.3 \%$ finished high school, $21.0 \%$ went to community college, $51.4 \%$ finished their undergraduate studies, while $10.7 \%$ went to graduate school. Majority of the respondents are married $(57.4 \%)$, with the rest being single $(42.6 \%)$.

\subsection{Procedure}

All participants received a paper-and-pencil questionnaire with an accompanying letter that explained the purpose of the survey, emphasized voluntary participation, and guaranteed confidently. Participants were asked to fill out the questionnaire and put it back into an envelope that was collected by the researcher.

\subsection{Measure}

Workplace bullying was measured using the Negative Acts Questionnaire-Revised (Einarsen \& Hoel, 2001) which was designed to measure three inter-related factors associated with person-related bullying (12 items), work-related bullying (7 items) and physically intimidating bullying (3 items). Workaholism was measured with the short Dutch Work Addiction Scale (Schaufeli, Shimazu, \& Taris, 2009), which consists of two dimensions. The first dimension, Working Compulsively (WC), includes five items and the second dimension, Working Excessively (WE), comprises five items as well. Burnout was assessed with two scales of the Dutch version (Schaufeli \& Van Dierendonck, 2000) of the Maslach burnout inventory-general survey (MBI-GS; Schaufeli et al., 1996): Exhaustion (5 items) and Cynicism (4 items). Perceived organizational support was measured using eight-items from the scale developed by Eisenberger, et al. (2001). All items were rated on a 5-point Likert scale.

\section{Analysis Result}

\subsection{Verification of Reliability and Validity}

The validity of variables was verified through the principal components method and factor analysis with the varimax method. The criteria for determining the number of factors is defined as a 1.0 eigen value. I applied factors for analysis only if the factor loading was greater than 0.5 (factor loading represents the correlation scale between a factor and other variables). The reliability of variables was judged by internal consistency as assessed by Cronbach's alpha. I used surveys and regarded each as one measure only if their Cronbach's alpha values were 0.7 or higher.

\subsection{Common Method Bias}

As with all self-reported data, there is the potential for the occurrence of common method variance (CMV) (MacKenzie \& Podsakoff, 2012; Podsakoff et al., 2003). To alleviate and assess the magnitude of common method bias, I adopted several procedural and statistical remedies that Podsakoff et al. (2003) suggest. First, during the survey, respondents were guaranteed of anonymity and confidentiality to reduce the evaluation apprehension. Further, we paid careful attention to the wording of the items, and developed our questionnaire carefully to reduce the item ambiguity. These procedures would make them less likely to edit their responses to be more socially desirable, acquiescent, and consistent with how they think the researcher wants them to respond when answering the questionnaire (Podsakoff et al., 2003; Tourangeau, Rips, \& Rasinski, 2000). Second, I conducted a Harman's one-factor test on all of the items. A principle components factor analysis revealed that the first factor only explained 35.2 percent of the variance. Thus, no single factor emerged, nor did one factor account for most of variance. Furthermore, the measurement model was reassessed with the addition of a latent common method variance factor (Podsakoff et al., 2003). All indicator variables in the measurement model were loaded on this factor. Addition of the common variance factor did not improve the fit over the measurement model without that factor with all indicators still remaining significant. These results do suggest that common method variance is not of great concern in this study.

\subsection{Relationship between Variables}

$<$ Table 1> summarizes the Pearson correlation test results between variables and reports the degree of multi-collinearity between independent variables. The minimum tolerance of 0.819 and the maximum variance inflation factor of 1.231 show that the statistical significance of the data analysis was not compromised by multi-collinearity. 
$<$ Table 1> Variables' correlation coefficient

\begin{tabular}{|c|c|c|c|c|c|c|c|c|}
\hline & $\mathbf{1}$ & $\mathbf{2}$ & $\mathbf{3}$ & $\mathbf{4}$ & $\mathbf{5}$ & $\mathbf{6}$ & $\mathbf{7}$ & $\mathbf{8}$ \\
\hline Job-related bullying & 1 & & & & & & & \\
\hline Person-related bullying & .000 & 1 & & & & & \\
\hline Threatening bullying & .000 & .000 & 1 & & & & \\
\hline Working compulsively & $.043^{\star \star}$ & -.116 & -.011 & 1 & & & \\
\hline Working excessively & $.108^{\star *}$ & $.082^{* *}$ & -.072 & -.111 & 1 & & \\
\hline Exhaustion & .034 & .033 & -.042 & .102 & $.115^{\star *}$ & 1 & \\
\hline Cynicism & .071 & .021 & .128 & .103 & -.011 & .000 & 1 & \\
\hline Perceived organizational support & -.027 & -.191 & -.043 & $-.042^{\star *}$ & $-.032^{* *}$ & $-.021^{*}$ & $-.110^{* *}$ & 1 \\
\hline
\end{tabular}

${ }^{*} p<.05,{ }^{* *} p<.01$

\subsection{Hypothesis Testing}

To analyze the relationship between workplace bullying and workaholism, the results in <Table 2> show that the sub-factors of workplace bullying has statistical significances with sub-factors of workaholism. Job-related bullying is positively related with working compulsively $(\beta=.101, p<.01)$ and working excessively $(\beta=.092, p<.01)$. Person-related bullying has positive relationships with working excessively $(\beta$ $=.032, \mathrm{p}<.01)$. However, threatening bullying has no significance with any sub-factor of workaholism. These imply that the more job-related bullying or person-related bullying employees perceive in the workplace, the stronger their workaholism is, which is suggested in the <hypotheses $1>$.

$<$ Table 2> Analysis 1

\begin{tabular}{|c|c|c|}
\hline \multirow{2}{*}{} & \multicolumn{2}{|c|}{ Workaholism } \\
\cline { 2 - 3 } & $\begin{array}{c}\text { Working } \\
\text { compulsively }\end{array}$ & $\begin{array}{c}\text { Working } \\
\text { excessively }\end{array}$ \\
\hline Sex & $.082^{*}$ & -.031 \\
\hline Age & -.010 & $.181^{* *}$ \\
\hline Educational level & .028 & -.021 \\
\hline Job-related bullying & $.101^{* *}$ & $.092^{* *}$ \\
\hline Person-related bullying & -.014 & $.032^{* *}$ \\
\hline Threatening bullying & -.091 & -.102 \\
\hline \hline Adj. $\mathrm{R}^{2}$ & .116 & .158 \\
\hline $\mathrm{F}$ & $7.461^{* *}$ & $9.433^{* *}$ \\
\hline
\end{tabular}

${ }^{*} p<.05,{ }^{* *} p<.01$

$<$ Table 3> summarizes the effects of sub-factors of workaholism on the sub-factors of burnout. It was found that working excessively has a positive effect on exhaustion ( $\beta=$ $.075, \mathrm{p}<.01)$. However, no sub-factors of workaholism has any significance with cynicism. These show that the stronger employees' workaholism is, the more exhausted they are, as expected in the <hypotheses 2>

In <Table 4>, model 1 and model 3 are the step 1 of Baron and Kenny (1986) and tests the relationship between workplace bullying and burnout. Job-related bullying has positive effect on exhaustion $(\beta=.125, p<.01)$. Personrelated bullying has positive effect exhaustion $(\beta=.063$, $p<$ .01). The step 2 of Baron and Kenny (1986) has already been shown in the results of Table 3 . In steps 3 and 4 of the mediation analysis, exhaustion was regressed on the control variables, the sub-factor of workplace bullying, and a sub-factor of workaholism which is significantly associated with burnout. Model 2 and model 4 indicate the results. The positive effect of job-related bullying on exhaustion is weaker $(\beta=.112, p<.05)$ when working excessively $(\beta=.019, p<$ .01 ) is entered into the equation, which is partial mediation. The positive effect of person-related bullying on exhaustion is weaker $(\beta=.044, p<.05)$ when working excessively $(\beta=$ $.109, p<.05)$ is entered into the equation, which is partial mediation. These results are confirmed by the Sobel tests ( $p<.05$ in all of significant cases). In the results, workplace bullying increases burnout through workaholism, which is expected in <hypotheses $3>$.

<Table 3> Analysis 2

\begin{tabular}{|c|c|c|}
\hline \multirow{2}{*}{ Sex } & \multicolumn{2}{|c|}{ Burnout } \\
\cline { 2 - 3 } & Exhaustion & Cynicism \\
\hline Age & $-.104^{\star}$ & -.031 \\
\hline Education level & $.181^{\star *}$ & $.199^{\star *}$ \\
\hline Working compulsively & .113 & .026 \\
\hline Working excessively & .104 & .034 \\
\hline Adj. $\mathrm{R}^{2}$ & $.075^{\star *}$ & -.017 \\
\hline $\mathrm{F}$ & .162 & .061 \\
\hline
\end{tabular}

${ }^{*} p<.05,{ }^{* *} p<.01$

$<$ Table 4> Analysis 3

\begin{tabular}{|c|c|c|c|c|}
\hline & \multicolumn{4}{|c|}{ Exhaustion } \\
\cline { 2 - 5 } & Model 1 & Model 2 & Model 3 & Model 4 \\
\hline Sex & $-.026^{\star}$ & $-.012^{\star}$ & -.022 & -.031 \\
\hline Age & .023 & .043 & $.021^{\star}$ & $.032^{*}$ \\
\hline Education level & .113 & .082 & .045 & .011 \\
\hline Job-related bullying & $.125^{\star *}$ & $.112^{*}$ & & \\
\hline Person-related bullying & & & $.063^{\star *}$ & $.044^{*}$ \\
\hline Working excessively & & $.019^{\star *}$ & & $.109^{\star}$ \\
\hline \hline Adj. $\mathrm{R}^{2}$ & .109 & .133 & .101 & .144 \\
\hline $\mathrm{F}$ & $7.251^{\star *}$ & $8.635^{\star *}$ & $7.174^{\star *}$ & $9.202^{* *}$ \\
\hline
\end{tabular}

${ }^{*} p<.05,{ }^{* *} p<.01$

Lastly, <Table 5>, consisting of moderators, shows the interactions between workplace bullying and POS on workaholism. POS was found to have a negative effect on 
the relationship between job-related bullying and working compulsively $(\beta=-.101, \quad p<.01)$, and the relationship between job-related bullying and working excessively $(\beta=$ $-.031, p<.01)$. Based on our results, when employees have higher POS in the workplace, workplace bullying has a weaker impact on their workaholism, which is expected in $<$ hypotheses 3>. These results demonstrated that positive relationships between workplace bullying and workaholism are weaker for employees high rather than low in POS (see $<$ Figure 1>).

$<$ Table 5> Analysis 4

\begin{tabular}{|c|c|c|c|c|}
\hline & \multicolumn{4}{|c|}{ Workaholism } \\
\hline & \multicolumn{2}{|c|}{$\begin{array}{c}\text { Working } \\
\text { compulsively }\end{array}$} & \multicolumn{2}{|c|}{$\begin{array}{c}\text { Working } \\
\text { excessively }\end{array}$} \\
\hline & Model 1 & Model 2 & Model 3 & Model 4 \\
\hline Sex & $.082^{*}$ & $.072^{\star}$ & -.031 & -.015 \\
\hline Age & -.010 & -.019 & $.181^{* *}$ & $.109^{*}$ \\
\hline Educational level & .028 & .062 & -.021 & -.034 \\
\hline Job-related bullying & $.101^{\star *}$ & $.099^{\star *}$ & $.092^{\star *}$ & $.074^{\star *}$ \\
\hline Person-related bullying & -.014 & -.023 & $.032^{\star *}$ & $.052^{\star *}$ \\
\hline Threatening bullying & -.091 & -.078 & -.102 & -.092 \\
\hline POS & & $-.022^{\star *}$ & & $-.031^{\star \star}$ \\
\hline Job-related bullying*POS & & $-.101^{\star \star}$ & & $-.109^{\star \star}$ \\
\hline Person-related bullying *POS & & -.013 & & -.071 \\
\hline Threatening bullying ${ }^{*} \mathrm{POS}$ & & .031 & & -.022 \\
\hline Adj. $R^{2}$ & .116 & .172 & .158 & .193 \\
\hline $\mathrm{F}$ & $7.461^{* \star}$ & $10.421^{* *}$ & $9.433^{\star *}$ & $11.291^{* *}$ \\
\hline
\end{tabular}

\section{Conclusions}

\subsection{The Summary of Results}

The purpose of the present study was to examine the

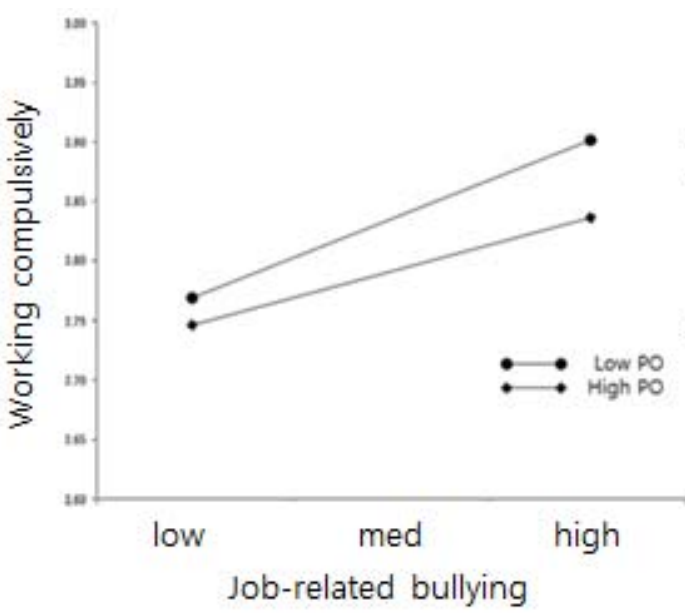

<Figure 1> Interaction effect

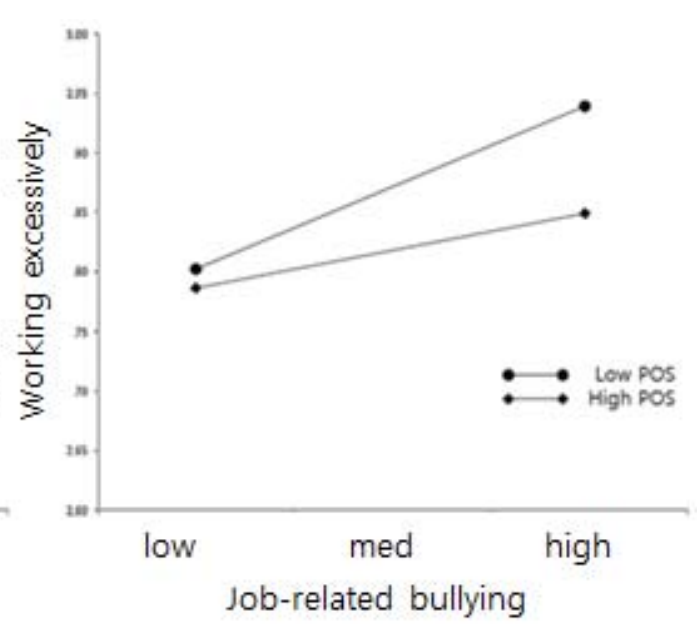

relationships between workplace bullying, workaholism, and burnout. Prevailing work suggests that workaholism might be preceded by maladaptive cognitions (McMillan et al., 2003), but research demonstrating this is nonetheless scarce. It was therefore hypothesized that situational antecedents, such as workplace bullying, would be precursors of workaholism (<Hypothesis 1>). And, workaholism would lead to burnout (<Hypothesis 2>). In order to substantiate the mediation, I also hypothesized that workplace bullying would increase burnout through workaholism (<Hypotheses $3>$ ). Finally, to explore the variable of moderation, I hypothesized that POS would decrease the effect of workplace bullying on burnout.

First, this study found that workplace bullying is indeed important in the workaholism process. It was found that job-related bullying promotes a compulsive and excessive drive to work. However, person-related bullying showed no significance with the tendency to work compulsively and was positively related to the tendency to work excessively hard. And threatening bullying had no relation with any of sub-factors of workaholism. These results shows that workaholsim is caused by bullying related to job or person. Especially, when employees cannot access the physical resources related to job due to bullying employees, because bullied employees become obsessive and try to get necessary resources in a long time. they tend to work compulsively and excessively in turn. However, when employees lose the psychological resources due to person-related bullying employees, bullied tend to work excessively to avoid additional loss of their psychological resources. And, threatening bullying show no significance with workaholism, which means that it may seldom appear in workplace. The sample of this research is based on responses from white-colored workers in South Korean companies, so there are more indirect bullying such as job-related or personal one than direct bullying such as threatening one. 
Second, the finding verified that workaholisom increases burnout. However, only working excessively shows significant relationship with exhaustion excepting cynicism. These results explain that devoting a great deal of time can deplete their resources to the point of near exhaustion than a compulsive drive to work. And in the results, workaholic employees are more exhausted than cynical.

Third, the results show the mediating role of workaholism between workplace bullying and burnout. Paradoxically, although bullied employees may reserve their personal resources through workaholism in short time, it drives them to be workaholic, which leads them exhausted in turn.

Finally, I found that POS decreases the relationship between workplace bullying and burnout. In the results, POS moderates the effect of job-related bulling on workaholism. Especially, when employees cannot access the physical resources related to job due to bullying employees, because perceived organizational support provides access to relevant resources at work, it help bullied employees access their necessary resources. Therefore, because they don't need to be become obsessive and try to get necessary resources in a long time, they don't work compulsively and excessively.

\subsection{Contributions and Limitations}

For research contribution, first, this study suggests workplace bullying as a situational antecedent and verify burnout as a consequence of workaholism. Second, it investigate the mediating role of workaholism and the moderation effect of POS. Practically, as the competition between the companies become stronger, workplace bullying can appear and it induce workaholism, which in turn, make employees exhausted. However, because workplace bullying is an informal behaviors, it is very difficult to find out these negative behaviors and prevent them either. Given this situation, corporate executives need to recognize the appearance of workplace bullying by monitoring the phenomena of employees' workaholism. When they find workaholic employees, they should investigate if workplace bullying exists through face-to-face talk. If necessary, they should decide personal transfer to the other department or work team.

By this research results, the present study could have several insights into the relationships between organizational behaviors and workaholism. However, it should also acknowledge the following limitations in this research. First, the present study collected the responses from white-colored employees who are working in business offices in South Korea. There may exist some nation cultural issues in the organizational context. A future study should re-test this in other workplaces in other countries in order to assure this results' reliability. Second, as the variables were all measured at the same time, it cannot be sure that their relationships are constant. Although the survey questions occurred in reverse order of the analysis model to prevent additional issues, the existence of causal relationships between variables is a possibility.

\section{References}

Andreassen, C. S., Ursin, H., \& Eriksen, H. R. (2007). The relationship between strong motivation to work, workaholism, and health. Psychology and Health, 22, 625-629.

Astrauskaite, M., Perminas, A., \& Kern, R. M. (2010). Sickness, colleagues' harassment in teachers' work and emotional exhaustion. Medicina (Kaunas), 46(9), 628-634.

Baron, R., \& Kenny, D. (1986). The Moderator-Mediator Variable Distinction in Social Psychological Research: Conceptual, Strategic and Statistical Considerations. Journal of Personality and Social Psychology, 51(6), 1173-1182.

Bowling, N. A., \& Beehr, T. A. (2006). Workplace harassment from the victim's perspective: A theoretical model and meta-analysis. Journal of Applied Psychology, 91(5), 998.

Buelens, M., \& Poelmans, S. A. Y. (2004). Enriching the Spence and Robbins' typology of workaholism: Demographic, motivational and organizational correlates. Organizational Change Management, 17, 459-470.

Burke, R. J. (1999). Workaholism in organizations: Psychological and physical well-being Consequences. Stress Medicine, 16, 11-16.

Einarsen, S., Hoel, H. (2001). The negative acts questionnaire: development, validation, and revision of a measure of bullying at work. In: 10th Annual Congress of Work and Occupational Psychology, Prague, Czech Republic.

Einarsen, S. (2005). The nature, causes and consequences of bullying at work: The Norwegian experience. Pistes, 7(3), 1-14.

Einarsen, S., Matthiesen, S., \& Skogstad, A. (1998). Bullying, burnout and well-being among assistant nurses. Journal of Occupational Health and Safety: Australia and New Zealand, 14(6), 563-568.

Eisenberger, R., Huntington, R., Hutchison, S., \& Sowa, D. (1986). Perceived organizational support. Journal of Applied Psychology, 71, 500-507.

Eisenberger, R., Armeli, S., Rexwinkel, B., Lynch, P. D., \& Rhoades, L. (2001). Reciprocation of perceived organizational support. Journal of Applied Psychology, 86, 42-51.

Hirschman, E. C. (1992). The consciousness of addiction: Toward a general theory of compulsive consumption. Journal of Consumer Research, 19, 
155-179.

Hobfoll, S. E. (1989). Conservation of resources: A new attempt at conceptualizing stress. American Psychologist, 44, 513-524.

Hobfoll, S. E. (2001). The influence of culture, community, and the nested-self in the stress process: Advancing conservation of resources theory. Applied Psychology, 50, 337-421.

Hobfoll, S. E. (2002). Social and psychological resources and adaptation. Review of General Psychology, 6, 307-324.

Hogh, A., Mikkelsen, E. G., \& Hansen, A. M. (2011). Individual consequences of workplace bullying/ mobbing. In S. Einarsen, H. Hoel, D. Zapf, \& C. L. Cooper (Eds.), Bullying and harassment in the workplace: Developments in theory, research and practice (pp.107-128). London, UK: Taylor \& Francis.

Kim, A., Oh, Y., \& Choi, B. (2016). Effects of LMX and Perceived Ethics with Leader on Job Burnout. Journal of Distribution Science, 14(8), 59-66.

MacKenzie, S. B., \& Podsakoff, P. M. (2012). Common method bias in marketing: Causes, mechanisms, and procedural remedies. Journal of Retailing, 88(4), 542-555.

Maslach, C. (1986). Stress, burnout and workaholism. In R. R. Killberg, P. E. Nathan, \& R. W. Thoreson (Eds.), Professionals in distress: Issues, syndromes and solutions in psychology (pp.53-73). Washington, DC: American Psychological Association.

McMillan, L. W., O’Driscoll, M. P., \& Burke, R. J. (2003). Workaholism: A review of theory, research, and future directions. In C. L. Cooper \& I. T. Robertson (Eds.), International review of industrial and organizational psychology (pp.167-189). New York, NY: Wiley.

McMillan, L., \& O'Driscoll, M. P. (2008). The wellsprings of workaholism: A comparative analysis of the explanatory theories. In R. J. Burke \& C. L. Cooper (Eds.), The long work hours culture: Causes, consequences and choices (pp.85-111). Bingley, UK: Emerald.

Moon, J., Chang, J., Lee, S., \& Kang, Y. (2016). The Effect of Perceived Organizational Support on Subjective Career Success: The Mediating Effect of Career Planning. Journal of Distribution Science, 14(2), 83 92.

Nielsen, M. B., \& Einarsen, S. (2012). Outcomes of exposure to workplace bullying: A meta-analytic review. Work \& Stress, 26(4), 309-332.

Ng, T. W. H., Sorensen, K. L., \& Feldman, D. C. (2007). Dimension, antecedents, and consequences of workaholism: A conceptual integration and extension. Journal of Organizational Behavior, 28, 111-136.

Oates, W. (1968). On being a "workaholic" (a serious jest). Pastoral Psychology, 19, 16-20.

Podsakoff, P. M., MacKensie, S. B., Lee, J.-Y., \& Podsakoff, N. P. (2003). Common method biases in behavioral research: A critical review of the literature and recommended remedies. Journal of Applied Psychology, 88(5), 879-903.

Porter, G. (1996). Organizational impact of workaholism: Suggestions for researching the negative outcomes of excessive work. Journal of Occupational Health Psychology, 1, 70-84.

Ray, E. B., \& Miller, K. I. (1994). Social support, home/ work stress, and burnout: Who can help?. Journal of Applied Behavioral Science, 30, 357-373.

Rhoades, L., \& Eisenberger, R. (2002). Perceived organizational support: A review of the literature. Journal of Applied Psychology, 87, 698-714.

Schaufeli, W. B., Shimazu, A., \& Taris, T. W. (2009). Being driven to work excessively hard. The evaluation of a two-factor measure of workaholism in the Netherlands and Japan. Cross-Cultural Research, 43, 320-348.

Schaufeli,W. B., Leiter,M. P., Maslach, C., \& Jackson, S. E. (1996). Maslach burnout inventory-General survey. In C. Maslach, S. E. Jackson,\&M. P. Leiter (Eds.), The Maslach Burnout Inventory: Test Manual (3rd ed. pp.22-26). Palo Alto, CA: Consulting Psychologists Press.

Schaufeli,W. B., \& Van Dierendonck, D. (2000). Handleiding van de Utrechtse Burnout Schaal (UBOS) [Manual Utrecht Burnout Scale]. Lisse: Swets Test Services.

Scott, K. S., Moore, K. S., \& Miceli, M. P. (1997). An exploration of the meaning and consequences of workaholism. Human Relations, 50, 287-314.

Sonnentag, S., \& Zijlstra, F. R. H. (2006). Job characteristics and off-job activities as predictors of need for recovery, well-being and fatigue. Journal of Applied Psychology, 91, 330-350.

Spence, J. T., \& Robbins, A. S. (1992). Workaholism: Definition, measurement, and preliminary results. Journal of Personality Assessment, 58, 160-178.

Taris, T. W., Geurts, S. A. E., Schaufeli, W. B., Blonk, R. W. B., \& Lagerveld, S. E. (2008). All day and all of the night: The relative contribution of two dimensions of workaholism to well-being in self-employed workers. Work and Stress, 22, 153-165.

Taris, T. W., Van Beek, I., \& Schaufeli, W. B. (2010). 
Why do perfectionists have a higher burnout risk than others? The mediational effect of workaholism. Romanian Journal of Applied Psychology, 12, 1-7.

ten Brummelhuis, L. L., \& Bakker, A. B. (2012). A resource perspective on the work-home interface: The work-home resources model. American Psychologist, 67, 545-556.

Thombs, D. L. (1994). Introduction to Addictive Behaviors. New York: The Guilford Press.

Tourangeau, R., Rips, L. J., \& Rasinski, K. (2000). The Psychology of Survey Response. Cambridge, U.K.: Cambridge University Press.

Van der Hulst, M. (2003). Long workhours and health.
Scandinavian Journal of Work, Environment and Health, 29, 171-188.

Van Wijhe, C. I., Peeters, M. C. W., Schaufeli, W. B., \& Ouweneel, A. P. E. (2013). Rise and shine: Recovery experiences of workaholic and nonworkaholic employees. European Journal of Work and Organizational Psychology, 22, 476-489.

Yang, H., Cho, H., \& Lee, Y. (2016). Multi-dimensional Emotional Intelligence Effects on Intrinsic/Extrinsic Motivation and Job Satisfaction: Analysis Using Laborer Perceived Organizational Support, The East Asian Journal of Business Management, 5(4), 13 18. 